\title{
Sharing Assets Potential in the Digital Transformation Conditions: The Example of Russia
}

\author{
Aleksandr Gostilovich \\ Faculty of Economics, Economics of Innovation Department, Lomonosov Moscow State University, Russia
}

Copyright $@ 2019$ by authors, all rights reserved. Authors agree that this article remains permanently open access under the terms of the Creative Commons Attribution License 4.0 International License

\begin{abstract}
Business digital transformation has been recently spreading through the world. In order to achieve a sustainable development, global society should implement the tools of digital transformation to optimize sharing assets. This phenomenon explains the growth of sharing economy. At the same time, the sharing economy is quite popular in the $\mathrm{C} 2 \mathrm{C}$ segment, but any thorough research is almost negated in the B2B segment. In this article, we will evaluate the potential of sharing economy in the context of modern sharing assets. On the grounds of qualitative and quantitative estimation of the statistical data the two new indices are introduced, which describe sharing assets potential in Russia. The results describe in this article can become the foundation for further and/or similar research conducted in other countries.
\end{abstract}

Keywords Sharing Economy, B2B Sharing, Sharing Assets, Digital Transformation, Resources Optimization

\section{Introduction}

Digitalization has become a priority in the state policy of many countries on a global scale. In business the digitalization processes are associated with the digital transformation of company business models. Digital transformation opens new horizons for business. The Sharing economy, which has expanded in the past few years, relies strongly on digital technologies [1]. The sharing economy is characterized by peer-to-peer interaction for renting of goods and services with the help of internet platforms [2]. The consulting company PwC has made a forecast for the growth of the Sharing economy market in the $\mathrm{C} 2 \mathrm{C}$ segment from 15 billion US dollars in 2015 to 335 billion US dollars in 2025. At the same time, sharing economy has an enormous potential for the B2B segment [3].

In Russia the number of transactions on both $\mathrm{C} 2 \mathrm{C}$ and B2C online platforms of Sharing economy services has increased by 30\% starting from 2017-2018 and is currently equal to 511 billion rubles [4]. Despite the lack of fundamental research in B2B Sharing Economy estimations, some representatives of the Russian business elites believe in its high potential. During the international economic forum in Saint Petersburg in 2018 it was stated that the Sharing Economy started to shift towards the B2B sector [5]. In the international science circles, there is a large research regarding this topic. Back in 2015 Michael J. Olson and Samuel J. Kemp together conducted a major research, where they managed to measure the Sharing Economy not only in the $\mathrm{C} 2 \mathrm{C}$ segment, but also made a number of important discoveries in the B2B segment [6]. The abovementioned research will be the basis for qualitative analysis of statistical information in relation to this article.

The problem of insufficient qualitative and quantitative research of the sharing economy was discussed in 2017 by Pablo Muñoz and Boyd Cohen in one of their research papers [7]. In their article they evaluated the $\mathrm{C} 2 \mathrm{C}$ segment. Some authors devote their attention to the Sharing Economy in the context of globalization spreading [8]. While estimating the ability of company business models in the Sharing Economy sphere to enter new global markets, it is important to consider the business environment of the countries where the company will do business.

This article contributes to the solution of problems described above. With the help of statistical data from the Federal State Statistics Service in respect to Russian companies, a set of key indicators will be formed [9]. This will help describe the degree of digitalization of companies and also estimate the level of under-utilized assets in the scope of the whole country. Then on the grounds of accumulated results and the analysis of existing publication on the topic two new indices will be introduced, which characterize a potential possibility of sharing assets between Russian companies. The results and developed methodology can later be implemented in similar research for other countries to evaluate the potential of the sharing economy. The conclusion might be of interest for the government officials, business representatives and scholars 
of emerging markets.

\section{Literature Review and Key Concepts}

Sustainable business development should become the goal of digital transformation for those companies which have an evolutionary character, and sharing economy would be a perfect match for this paradigm [10]. Crowdsourcing is a good example of sharing economy integration into corporate business models and production of added value with the help of a new model of workforce organization [11]. This might raise questions regarding sharing economy segmentation in order for a company to achieve its target values [12]. At the same time, the estimation of the feasibility of sharing systems integration requires knowledge and ability to evaluate already existing practice of sharing economy in different fields, each of them being a unique practical scope of application, when an achieved sustainable development is one of the priorities. A good example of this kind is hospitality Sector [13].

There has been a significant shift in the consumers' behavior, people started to understand and appreciate the benefits of shared use 10 years ago [14]. But what about business? What possible benefits can be achieved by the industrial companies with the shared use principle? Digital technologies force companies to reassess their business models. This is both a complicated and a creative process [15]. Yet, the issues typical for the C2C segment are also true to some extent for the B2B sharing. One of such issues is the problem of trust, which is the major obstruction on the way of sharing economy development [16]. In addition to the question of feasibility of the shared use application by business in general, there is also the question of theoretical possibility of this use. Currently there are not so many research papers and publications in this topic. The article written by Michael J. Olson and Samuel J. Kemp in 2015, made a significant contribution to the solution of this problem; the authors just predict possible integration of the underused assets in ERP systems of industrial companies [6].

Thus, on the one hand there is a demand from the society, and on the other one the companies have a potential for the shared use of assets. Sharing economy can solve different problems of modern society [17]. It is crucial to use resources of shared consumption in order to achieve the goal of sustainable development [18]. Additionally, already existing companies should pass through a complex mechanism of adaptation towards the volatile business environment [19]. Multiple researches show that sharing economy opens the new possibilities for the corporate business models [20], but what about the readiness of business infrastructure to adapt and implement the best practice of shared economy in order to optimize their operation? The goal of this research paper is to fill the gaps in the field of estimation of sharing economy spreading potential in B2B sector through the business environment of a specified country - Russia.

\section{Research Model and Hypothesis}

In Russia there is a program for monitoring the IT society development. The set of relations developing in production processes related to the penetration of digital technologies aimed at improving the competitiveness of business and the country forms Industry 4.0. In the Russia, this term means digital transformation of all sectors of the economy [21]. Based on theoretical discoveries of the consulting company PwC and Michael J. Olson together with Samuel J. Kemp [3], [6], we have selected certain key indices of development, which characterize the level of readiness of companies for sharing assets. In this research paper we use the following groups of indices of digital economy development in Russia: integration of internal information systems and shared access to information inside a company; integration of the information organization systems with the information systems of counterparties. The first group consists of the following indices: the number of companies, which are equipped with special software tools to control the purchase of goods (work, services); the number of companies equipped with special software tools to control the sales of goods (work, services), from the total number of studied companies; the number of companies using ERP systems, from the total number of studied companies; the number of companies using CRM systems, from the total number of studied companies; the number of companies using an electronic document management system, from the total number of studied companies. The second group of indices includes the following ones: the number of companies using electronic data exchange between the internal and external information systems, from the total number of studied companies; the number of companies using SCM systems, from the total number of studied companies.

This research paper considers all of the abovementioned indices in their dynamics starting from 2011 and until 2017. The growth rate for the specified indices was also calculated.

In order to estimate the condition of the under-utilized assets of Russian companies, a series of analysis-driven operations was conducted with respect to an average annual manufacturing capacity for machinery and equipment, electric equipment, electronic and optical equipment, transport vehicles and associated equipment.

On the basis of gathered data this research paper provides the calculations for the two indices. The index of digital transformation $-\mathrm{I}_{\mathrm{dt}}$ and the level of under-utilized assets - $I_{\text {uиa }}$. Digital transformation index is calculated as a common average between values of the abovementioned 
groups: integration of internal information systems and shared access to information inside the company (5 indices); integration of information systems of the company with the information systems of counterparties (2 indices). The equation below can be used to calculate the level of under-utilized assets (1).

$$
\mathrm{I}_{\text {uua }}=1-\left(\mathrm{I}_{\text {ua } 1}+\mathrm{I}_{\text {ua } 2}+\mathrm{I}_{\text {ua3 }}+\mathrm{I}_{\text {ua } 4}+\mathrm{I}_{\text {ua5 }}+\mathrm{I}_{\text {ua6 }}+\mathrm{I}_{\text {ua } 7}\right) / \mathrm{n}
$$

In this equation the value $I_{\text {ua1,2,3,4,5,6,7 }}$ is the level of average annual manufacturing capacity regarding some type of product. In total, the number of product types is equal to the value " $n$ " from this equation.

Thus, the calculated indices lie between the values of 0 and 1 . The closer is the index value to 1 , the higher is the level of company readiness for sharing assets.

\section{Results and Discussion}

The indices, which characterize the degree of integration of internal information system and the shared access to information within a company, are on completely different levels, yet, within the scope of its own dynamics from 2011 to 2017 each index has only insignificant changes. Table 1 shows the percentage ratio alterations in the dynamics for the indices under discussion.

The number of companies using ERP systems, from the total number of studied companies, and the number of companies using CRM systems, from the total number of studied companies, are leading with their growth rates. This is due to the rising global business competition.

Figure 1 shows the dynamics of natural alteration of indices from the second group, which characterize the integration of company information systems with the information systems of counterparties.

Table 1. Percentage ratio alterations

\begin{tabular}{|c|c|c|c|c|c|c|c|}
\hline & 2012 & 2013 & 2014 & 2015 & 2016 & 2017 & $\begin{array}{l}\text { Average } \\
\text { growth rate }\end{array}$ \\
\hline $\begin{array}{l}\text { Number of companies with special software tools for purchase } \\
\text { management of goods (work, services), from the total number } \\
\text { of studied companies }\end{array}$ & $0 \%$ & $7 \%$ & $-6 \%$ & $6 \%$ & $-2 \%$ & $-4 \%$ & $0 \%$ \\
\hline $\begin{array}{l}\text { Number of companies with special software tools for sales } \\
\text { management of goods (work, services), from the total number } \\
\text { of studied companies }\end{array}$ & $-6 \%$ & $0 \%$ & $-11 \%$ & $8 \%$ & $0 \%$ & $1 \%$ & $-1 \%$ \\
\hline $\begin{array}{l}\text { Number of companies using ERP systems, from the total } \\
\text { number of studied companies }\end{array}$ & $5 \%$ & $15 \%$ & $35 \%$ & $-8 \%$ & $15 \%$ & $14 \%$ & $13 \%$ \\
\hline $\begin{array}{l}\text { Number of companies using CRM systems, from the total } \\
\text { number of studied companies }\end{array}$ & $9 \%$ & $14 \%$ & $26 \%$ & $38 \%$ & $-5 \%$ & $10 \%$ & $15 \%$ \\
\hline $\begin{array}{l}\text { Number of companies using an electronic document } \\
\text { management system, from the total number of studied } \\
\text { companies }\end{array}$ & $-2 \%$ & $2 \%$ & $-5 \%$ & $6 \%$ & $5 \%$ & $0 \%$ & $1 \%$ \\
\hline
\end{tabular}

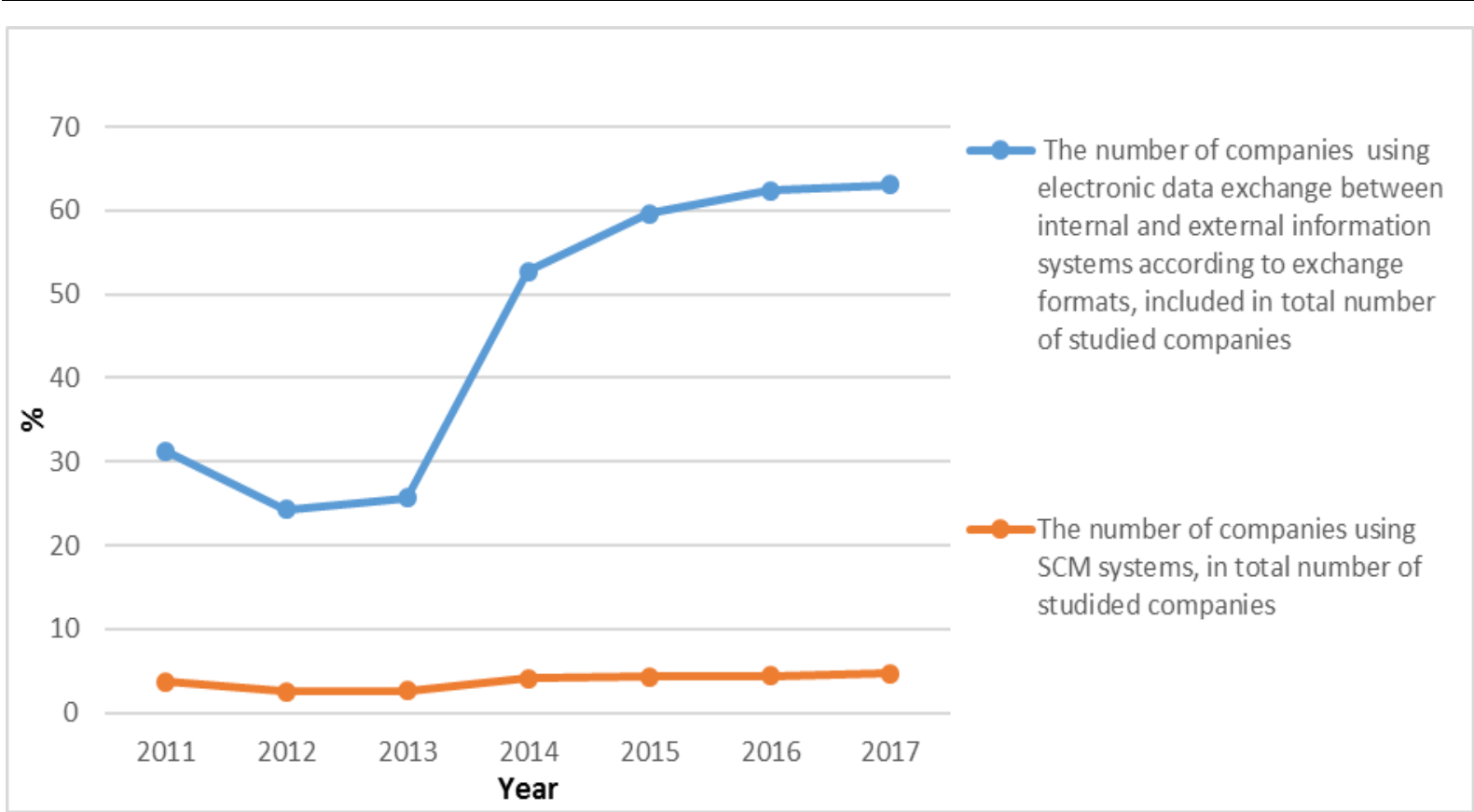

Figure 1. Integration of company information systems with the information systems of counterparties 
It is worth mentioning the initial sharp growth followed by a steady exponential growth of the number of companies using electronic data exchange between internal and external information systems according to exchange formats, among the total number of companies. This index has more than doubled its value in the period of time between 2011 and 2017.

On the grounds of the abovementioned values the digital transformation index Idt has been calculated. Figure 2 illustrates the dynamics of development for this index.
Digital transformation index is growing after its fall in 2012. During the past three years the growth rate has slowed down, yet, the overall trend remains positive.

Figure 3 illustrates the changes in growth dynamics starting from 2011 and up to 2017 regarding the index of under-utilized assets. This index was calculated on the basis of employment of average annual production capacity of companies manufacturing machinery and equipment, electric equipment, electronic and optical equipment, transport vehicles and associated equipment.

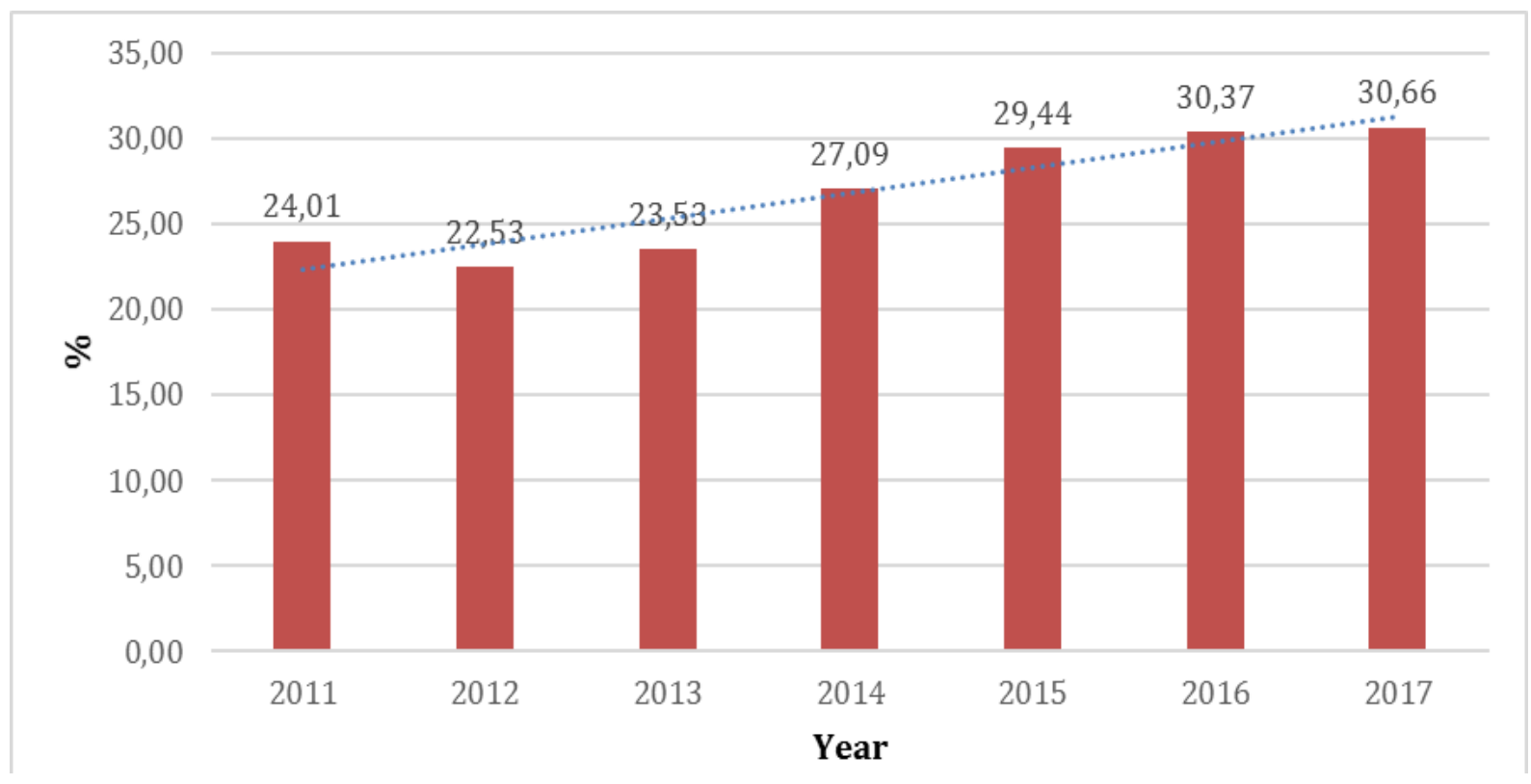

Figure 2. The index of digital transformation of Russian companies

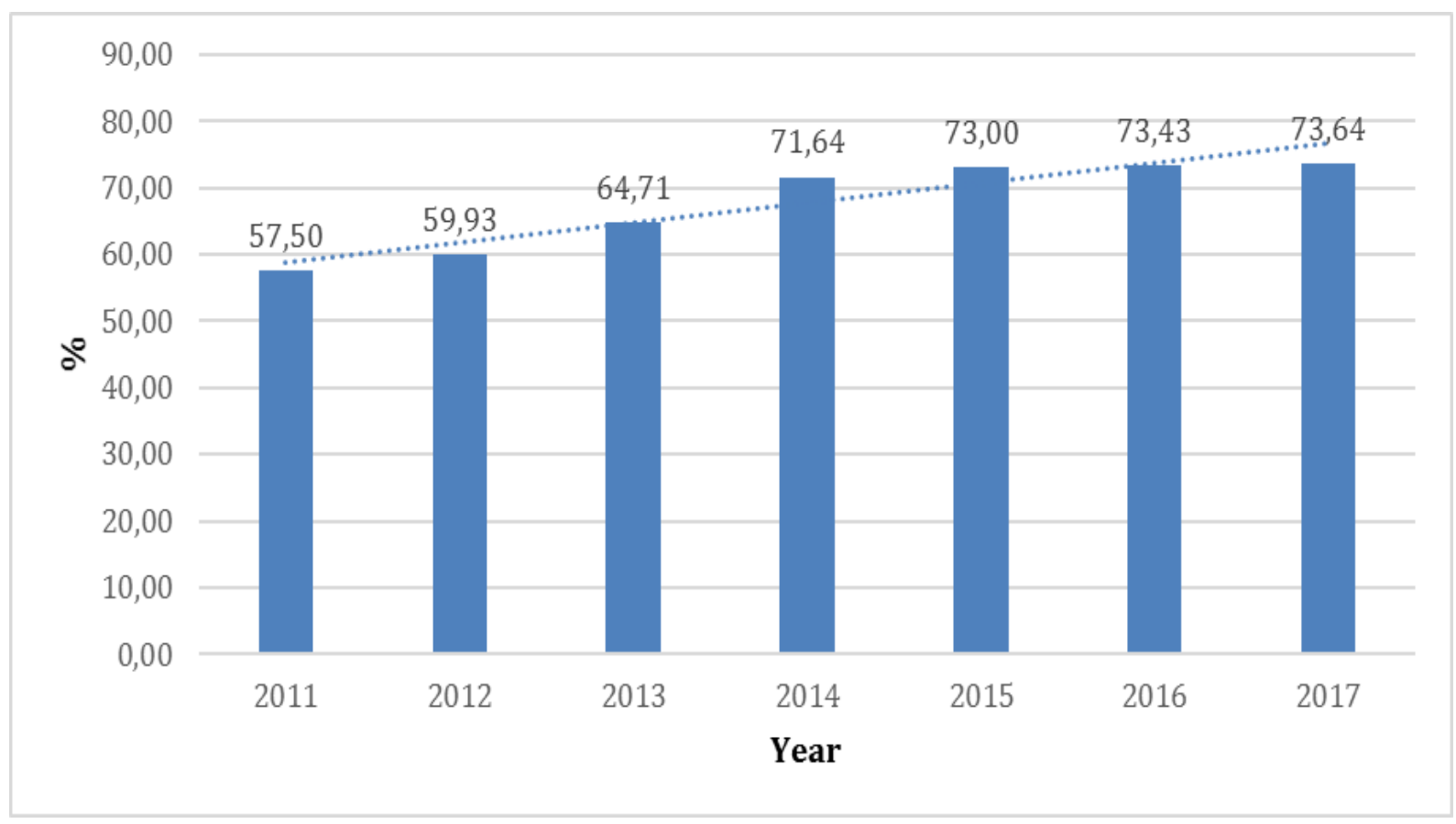

Figure 3. The level of under-utilized assets of Russian companies 
Growth of this aggregated index does not have any positive effects for the economy of a country. In fact, it means the growth of the number of production capacities that bring no added value. In comparison with 2011, the year 2017 shows the growth of this index by $28 \%$. The growth of digital transformation index in the period of time from 2011 to 2017 has also reached 28\%.

\section{Conclusions}

Research results published in this paper show that the potential of sharing assets among Russian companies is quite high and it keeps growing with time. For example, in 2017 the digital transformation index was $30.66 \%$, and the level of under-utilized assets reached $73.64 \%$. A sustainable growth by $28 \%$ has been noticed during the interval between 2011 and 2017. Digital technologies drive the development of sharing economy. That is why, both the growth of digital transformation index and the under-utilized assets level create a potential for the expansion of sharing assets among Russian companies. In Europe there is a digital platform, which allows small and large business enterprises to lend their production capacities and unused equipment [6]. The conducted research proves high potential of Russian business environment for adaptation and spreading of similar business models. Author of this article hopes that the results and methodology of the conducted research will lay the foundation for further inquiries among scholars and business think tanks.

\section{REFERENCES}

[1] Huckle S, Bhattacharya R, White M, Beloff N. Internet of Things, Blockchain and Shared Economy Applications International, Workshop of data mining and IoT Systems (DaMis 2016), No 98, 461-466, 2016

[2] Ganapati S, Reddick C. Prospects and challenges of sharing economy for the public sector, Government Information Quarterly, No 35, 77-87, 2017

[3] PWC. The Sharing Economy, 2015 URL: https://www.pwc.fr/fr/assets/files/pdf/2015/05/pwc_etude_ sharing_economy.pdf

[4] RAEC. Sharing Economy in Russia, 2018URL: https://raec.ru/upload/files/raec-sharing-economy-nov2018 .pdf

[5] St. Petersburg International Economic Forum. Share and earn The Sharing Economy Expert opinion, 2018 URL: https://roscongress.org/sessions/delis-i-zarabatyvay-ekono mika-sovmestnogo-potrebleniya/expert/

[6] Olson M, Kemp S. Sharing Economy: An In-Depth Look At Its Evolution \& Trajectory Across Industries, Piper Jaffray Investing Research, 2015
[7] Munoz P, Cohen B. Mapping out the sharing economy: A configurational approach to sharing business modeling, Technological Forecasting \& Social Change, No 125, 21-37, 2017

[8] Ronaldo C. Parentea, José-Mauricio G Geleilateb, Ke Rongc. The Sharing Economy Globalization Phenomenon: A Research Agenda, Journal of International Management, No 24, pp. 52-64, 2018

[9] Federal State Statistics Service URL: https://www.pwc.fr/fr /assets/files/pdf/2015/05/pwc_etude_sharing_economy.pdf

[10] Schaltegger, S., Ludeke-Freund, F., Hansen, E.G., 2016. Business models for sustainability: a co-evolutionary analysis of sustainable entrepreneurship, innovation, and transformation. Organ. Environ. 29 (3), 264-289

[11] Kohler, T., 2015. Crowdsourcing-based business models: how to create and capture value. Calif. Manag. Rev. 57 (4), 63-84.

[12] Hellwig, K., et al., 2015. Exploring different types of sharing: a proposed segmentation of the market for "sharing" businesses. Psychol. Mark. 32 (9), 891-906.

[13] Bangel, M., 2016. Sharing Economy-Threat or Opportunity? Exploring How Established Industries Can Leverage Emerging Collaborative Practices and Create New Sustainable Business Models for The European Hospitality Sector. Second International Workshop on the Sharing Economy (Paris).

[14] Botsman, R., \& Rogers, R. (2011). What's mine is yours: How collaborative consumption is changing the way we live. London: Collins.

[15] Johnson, M. W., Christensen, C. M., \& Kagermann, H. (2008). Reinventing your business model. Harvard Business Review, 86(12), 50-59.

[16] Houston, D. A. (2001). Trust in the networked economy: Doing business on web time. Business Horizons, 44(2), 38-44.

[17] Dillahunt, T. R., \& Malone, A. R. (2015). The promise of the sharing economy among disadvantaged communities. In Proceedings of the 33rd Annual ACM Conference on Human Factors in Computing Systems (pp. 2285-2294).

[18] Prothero, A., Dobscha, S., Freund, J., Kilbourne, W. E., Luchs, M.G., Ozanne, L. K., et al. (2011). Sustainable consumption: Opportunities for consumer research and public policy. Journal of Public Policy and Marketing, 30(1), 31-38.

[19] Matzler, K., Veider, V., \& Kathan, W. (2015). Adapting to the sharing economy. MIT Sloan Management Review, 56(2), 71-77.

[20] Kathan W, Matzler K, Veider V. (2016). The Sharing Economy: Your Business Model's Friend or Foe? Business Horizons (2016) 59, 663-672.

[21] Lapidus L, Digital Economy: E-Business and E-Commerce Management, INFRA-M, Moscow, 2019. 